\title{
Balance Between Risk And Profit In The Context Of Strategic Management: The Example Of Ukrainian Banks
}

\author{
https://doi.org/10.21272/sec.4(1).111-121.2020
}

Tatiana Goncharenko, ORCID: https://orcid.org/0000-0001-6298-4517

$\mathrm{PhD}$, Director of Sumy College of Economics and Trade, Sumy College of Economics and Trade, Ukraine

Liliana Lopa, ORCID: https://orcid.org/0000-0002-1806-6038

PhD Candidate, Department of Finance and Entrepreneurship, Sumy State University, Ukraine

\begin{abstract}
The article explores the issues of strategic management of banks, the formation of long-term strategic goals, in particular - the construction of an effective financial strategy of the bank aimed at finding a balance between the need for risk minimization and profit maximization. Balanced risk and return management should protect economic entities from potential income shortfalls or a reduction in the market value of capital due to adverse effects of external or internal factors, from losses that can be both direct (loss of income or capital) and indirect (investment). the ability to achieve your business goals). The article presents the author's own approach to the calculation of the taxonomic method of the bank's integrated risk and profitability indicators, as well as the results of matrix analysis, which made it possible to trace the bank's risk / profit ratio. All Ukrainian banks are selected as the subject of study, and the first three quarters of 2018 are the time horizon. Economic norms and limits of open currency position on regulation of banking activity by the National Bank of Ukraine were selected to assess the level of riskiness of the bank, and the main indicators of bank profitability (total level, cost recovery, return on assets, total capital, net interest margin) were selected for profitability level. The study empirically confirms that risk management in Ukrainian banks is at a critical level and profit management is at medium and low levels. Basically, banks are characterized by a focus on profit maximization, eliminating high risk activity. The risk-reward strategy is chosen by a small number of Ukrainian banks and profit maximization is rare enough for Ukrainian banks.
\end{abstract}

Keywords: strategy, bank, strategic management, risk management, profit management, taxonomic analysis, matrix analysis.

JEL Classification: G21, G28.

This work is licensed under a Creative Commons Attribution 4.0 International License.

Cite as: Goncharenko, T., Lopa L. (2020). Balance Between Risk And Profit In The Context Of Strategic Management: The Case Of Ukrainian Banks. SocioEconomic Challenges, 4(1), 111-121. https://doi.org/10.21272/sec.4(1).111-121.2020.

(C) The Authors, 2020. This article is published with open access at Sumy State University.

\section{Introduction}

In the current conditions of economic and political instability in Ukraine, the current reform of most areas of activity, including the banking sector, banks are exposed to numerous risks that arise in the external environment. In such circumstances, incorrect management decision can also cause internal bank problems, such as insolvency or even bankruptcy. It is in this context that the issue of banking risk management and, accordingly, profit as the main financial result of the activity is quite relevant and needs special attention in the formulation and implementation of the financial strategy of any commercial bank. The purpose of this paper is to propose a proprietary approach to assessing the risk and profitability of a commercial bank. 


\section{Literature review}

Numerous scientific works form a heoretical basis for the study of the peculiarities of the bank's financial strategy in the context of its strategic management, in particular: Vlasov K.E., Kirov Ye.V. (2010), Goncharenko O.M. (2015), Gorbunova S.V. (2010), Kaylyuk E.M., Andreeva V.M., Grynenko V.V. (2010), Krasnova I.V., Kotsyuba I.I. (2014), Kozmenko S.M., Shpyga F.I., Voloshka I.V. (2010), Lysychkin V.A., Lysychkina M.V. (2007), Sokyryns'ka I.H., Zhuravlyova T.O. (2016) and the like.

So, here is a definition of Vlasov K.E. and Kirov O.V. (2010) as the most typical and generic in the academic community: "it is a long-term course of purposeful financial management to achieve organizational-wide strategic goals." This definition also emphasizes the long-term nature of its development and strategic orientation, which are important aspects in understanding strategic financial management. Instead, Kaylyuk E.M. (2010) adds important aspects to the purpose of its development: "it is a general plan for determining financial results and financial needs, as well as alternative sources of funding to minimize the cost of capital and profit maximization". It is the profit maximization and the capital cost minimization, or, as other scholars add the risk activity minimization (Kyryzleeva A.S., 2016) and they are considered one of the main areas of financial strategy and in particular managing the bank assets and liabilities. Determining their optimal ratio is an important task for the bank's management and is taken into account in forming the fundamental principles of the financial strategy.

It should be noted that the issue of banking risks in their variety of types and forms also constituted an important object of numerous studies, among which we will note: Bobyl V. (2007), Boykivska L.I. (2009), Vnykova H.M., Menshova A.Yu. (2009), Salo I., Verhusha N. (2014) etc. At the same time, the main risk of the bank, according to most of these scientists is precisely "the likelihood of a loss of income or a decrease in the market value of a bank's capital due to adverse external or internal factors". Profit management is an integral part of a financial strategy focused on managing your own financial results. It was studied in detail and in the works mentioned above and it is important to note the works of Krykliy O.A., and Maslak N.G. (2008), Lysenok O.V. (2011), etc.

All the above works make an unvalued contribution to the development of a quality financial strategy of a commercial bank, however, the question of evaluating the integrated indicators of risk and profitability of the bank remains, which will underlie further management decisions and formulation of financial strategy goals.

\section{Methodology and research methods}

To develop appropriate financial strategies for commercial bank development within strategic management with goals in mind, risk minimization and profit maximization, we propose to calculate the integral indicators in both directions and to determine the place of banks in the ratio banking risk management and profit management.

Integrated metrics is commonly used to map objects with many different attributes. One of the methods of their calculation is taxonomic analysis, which has several advantages, among which we propose to distinguish:

$>$ it is focused on the research of objects with a large number of heterogeneous parameters;

$>$ it allows to collapse multidimensional statistical material into a single integral indicator;

$>$ it solves the problem of ordering multidimensional objects or processes by applying reference values;

$>$ it has a well-defined evaluation scale that simplifies the process of results interpretation (acquire values from 0 to 1 ) and the like.

The basis of this method is the determination of the so-called taxonomic distance, i.e. the distance between the points of the multidimensional space, the dimension of which is determined by the number of features that characterize the object under study. Determining these distances makes it possible to determine the location of each particular point relative to the others, and thus to structure the entire set of points (Litvinova, 2012).

The general methodology for calculating the taxonomic index is shown in Figure 1. 


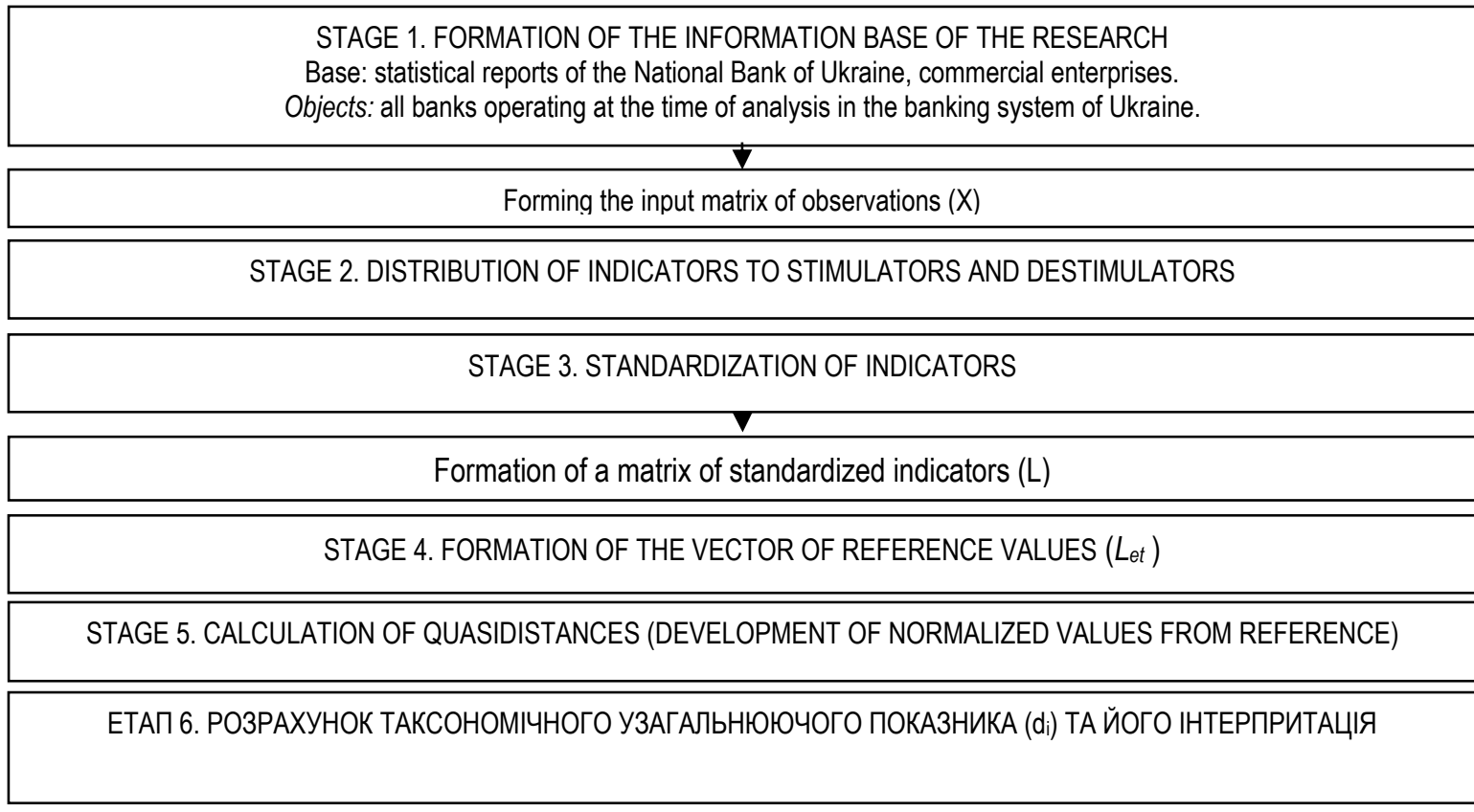

Figure 1. General method for calculating taxonomic index

Source: compiled by author.

In the first stage of the analysis, it is necessary to form a so-called observation matrix. Let's suppose we have a set of $m$ units that are described by different attributes in the number $n$ units. Each unit can be understood as a point of $n$-dimensional space with defined coordinates. That is, the above observation matrix will have the following form (Lytvynova, 2012):

$$
X=\left(\begin{array}{ccccc}
x_{11} & \ldots & x_{1 j} & \ldots & x_{1 n} \\
\ldots & \ldots & \ldots & \ldots & \ldots \\
x_{i 1} & \ldots & x_{i j} & \ldots & x_{i n} \\
\ldots & \ldots & \ldots & \ldots & \ldots \\
x_{m 1} & \ldots & x_{m j} & \ldots & x_{m n}
\end{array}\right)
$$

where $X$ is the matrix of indicators; $i$ is the number of the corresponding indicator (from 1 to $n$ ); $j$ is a number of the corresponding bank (from 1 to $m$ ); $x_{i j}$ is the $i$-th indicator for the $j$-th bank.

$\mathrm{n}$ the second stage, certain indicators are evaluated as stimulants or stimulants. For this purpose, the nature of the indicator impact (positive or negative) on the level of development or bank activity is analyzed. This division is the basis for further stages of analysis.

The input data set is heterogeneous because it describes different features of objects and has different units of measure and so on. A standardization procedure is being conducted to bring the indicators to a comparable perspective. To do this, we use the following formulas (Lytvynova, 2012):

$$
\begin{aligned}
& l_{i j}=\frac{x_{i j}-\bar{x}_{i}}{\sigma_{i}} \\
& \bar{x}_{i}=\frac{1}{m} \sum_{j=1}^{n} x_{i j} \\
& \sigma_{i}=\sqrt{\frac{1}{m} \sum_{j=1}^{n}\left(x_{i j}-\bar{x}_{i}\right)^{2}}
\end{aligned}
$$


where $l_{i j}$ is the normalized $i$-th indicator for the $j$-th bank; $\bar{x}_{i}$ is the average value of the $i$-th indicator for the considered set of banks; $\sigma_{i}$ is the standard deviation of the $i$-th indicator for the considered set of banks.

hus, the standardized matrix indicators will look like this:

$$
L=\left(\begin{array}{ccccc}
l_{11} & \ldots & l_{1 j} & \ldots & l_{1 n} \\
\ldots & \ldots & \ldots & \ldots & \ldots \\
l_{i 1} & \ldots & l_{i j} & \ldots & l_{i n} \\
\ldots & \ldots & \ldots & \ldots & \ldots \\
l_{m 1} & \ldots & l_{m j} & \ldots & l_{m n}
\end{array}\right)
$$

where $L$ is the matrix of normalized indicators.

The next, the fourth stage is the formation of a vector of benchmark values. It is usually represented as a column matrix. Moreover, it is proposed to choose this value as the maximum (if the factor is a stimulant, ie its increase affects the result) or the minimum (if the factor is a stimulant). In addition, it is advisable to accept the assumption that banks cannot reach the benchmark, which requires an adjustment of the standard deviation. Mathematically, the vector formation of reference values can be represented as follows:

$$
\begin{gathered}
L_{e t}=\left(\begin{array}{c}
l_{1 e t} \\
\ldots \\
l_{i e t} \\
\cdots \\
l_{m e t}
\end{array}\right) \\
l_{1 e t}=\left[\begin{array}{l}
\max \left(x_{i j}\right) \\
\min \left(x_{i j}\right)
\end{array}+\sigma_{n}\right.
\end{gathered}
$$

where $L_{e t}$ is a vector of benchmark values; $l_{i e t}$ is the normalized $i$-th indicator of a reference bank.

During the fifth stage the normalized values of indicators should be compared with the standard values for calculating the quasi-distances according to the following formula (Lytvynova, 2012):

$$
c_{i 0}=\sqrt{\sum_{i=1}^{m}\left(l_{i j}-l_{i e t}\right)^{2}}
$$

where $c_{i 0}$ is the quasi-distance between the jth and the reference subject.

The last stage in taxonomic analysis is to determine the integral index. To do this, the following calculations are needed (Lytvynova, 2012):

$$
\begin{aligned}
& d_{i}=1-\frac{c_{i 0}}{c_{0}} \\
& c_{0}=\bar{c}_{0}+2 S_{0} \\
& \bar{c}_{0}=\frac{1}{m} \sum_{i=1}^{m} c_{i 0} \\
& S_{0}=\sqrt{\frac{1}{m} \sum_{i=1}^{m}\left(c_{i 0}-\bar{c}_{0}\right)^{2}}
\end{aligned}
$$

where $d_{i}$ is an integral taxonomic indicator. 
It is considered that the interpretation of this indicator is as follows: it assumes high values at large values of stimulants and low values at small values of stimulants (Perepelova, 2013).

The closer it is to one, the better the risk management of a particular commercial bank is.

\section{PART 1: Assessing the taxonomic indicator of bank riskiness}

Banking risk assessment is challenging enough because of its wide variety and unpredictability. In our work, we propose to use economic norms and limits of open currency position to regulate banking activity to evaluate the integral risk index of the bank. They are used as one of the main tools of the NBU for ensuring the stability of the banking system and detecting and preventing crisis phenomena based on the analysis of an individual bank. That is why they were selected as the basis for the study. Regarding the time range, we have chosen the first three quarters of 2018, because during this period of time the existing banks in the banking system were relatively comparable, which allows us to compare the dynamics of their change. In the course of our research, the information base for assessing banking risks will be the main indicators of economic standards and limits of open currency position on all available banks in the system in a certain time range (Table 1).

Table 1. The characteristics of main variables for assessing the taxonomic indicator of banking risks

\begin{tabular}{|c|l|l|}
\hline Variable & \multicolumn{1}{|c|}{ Characteristics } & \multicolumn{1}{|c|}{ Direction of influence } \\
\hline $\mathrm{x}_{1}$ & H1, the amount of regulatory capital & Stimulator \\
\hline $\mathrm{x}_{2}$ & $\mathrm{H}$, standard of adequacy (adequacy) of regulatory capital (not less than 10\%) & Stimulator \\
\hline $\mathrm{x}_{3}$ & $\mathrm{H} 4$, instant liquidity ratio (not less than 20\%) & Stimulator \\
\hline $\mathrm{x}_{4}$ & H5, current liquidity ratio (at least 40\%) & Stimulator \\
\hline $\mathrm{x}_{5}$ & $\mathrm{H}$, short-term liquidity ratio (not less than 60\%) & Stimulator \\
\hline $\mathrm{x}_{6}$ & $\mathrm{H}$ 7, maximum credit risk limit per counterparty (max 25\%) & Destimulator \\
\hline $\mathrm{x}_{7}$ & $\mathrm{H} 8$, high credit risk ratio (max 8x regulatory capital) & Destimulator \\
\hline $\mathrm{x}_{8}$ & $\mathrm{H} 9$, maximum credit risk ratio for transactions with bank related entities (max 25\%) & Destimulator \\
\hline $\mathrm{x}_{9}$ & $\begin{array}{l}\mathrm{H} 11, \text { the standard of investment in securities separately for each institution (not more } \\
\text { than 15\%) }\end{array}$ & Destimulator \\
\hline $\mathrm{x}_{10}$ & $\mathrm{H} 12$, standard of the total amount of investment (not more than 60\%) & Destimulator \\
\hline $\mathrm{x}_{11}$ & $\begin{array}{l}\text { L13-1, the risk standard for the common long open currency position (no more than } \\
5 \%)\end{array}$ & Destimulator \\
\hline $\mathrm{x}_{12}$ & $\begin{array}{l}\text { L13-2, the risk standard for the common short open currency position (not more than } \\
5 \%)\end{array}$ & Destimulator \\
\hline
\end{tabular}

Source: compiled by author.

We analyze the main characteristics of the input data with the help of descriptive statistics function, which allows us to determine the average values, standard deviations, minimum and maximum values for the sample (Table 2).

Table 2. Descriptive statistics for the of the taxonomic indicator assessment of banking risk assessment as of 01.03.2018

\begin{tabular}{|c|c|c|c|c|c|}
\hline Variable & $\begin{array}{c}\text { Number of } \\
\text { observations }\end{array}$ & Mean value & Standard deviation & Minimum value & Maximum value \\
\hline $\mathrm{X}_{1}$ & 84 & 1452658,73 & 3437685,70 & $-7572024,81$ & 22275400,03 \\
\hline $\mathrm{x}_{2}$ & 84 & 68,78 & 147,99 & 0,00 & 1197,63 \\
\hline $\mathrm{X}_{3}$ & 84 & 409,04 & 1965,99 & 9,22 & 17596,90 \\
\hline $\mathrm{X}_{4}$ & 84 & 1022,31 & 7569,66 & 15,43 & 69298,89 \\
\hline $\mathrm{X}_{5}$ & 84 & 1023,24 & 7571,29 & 15,38 & 69298,89 \\
\hline $\mathrm{X}_{6}$ & 84 & 592799542,97 & 5228371252,12 & 0,02 & 47904279508,00 \\
\hline $\mathrm{X}_{7}$ & 84 & 13111974693,19 & 110621493493,10 & 0,00 & 1010906527038,00 \\
\hline $\mathrm{X}_{8}$ & 84 & 46495,26 & 425839,74 & 0,00 & 3902918,00 \\
\hline $\mathrm{X}_{9}$ & 84 & 0,34 & 1,30 & 0,00 & 10,02 \\
\hline $\mathrm{X}_{10}$ & 84 & 0,43 & 1,51 & 0,00 & 10,04 \\
\hline $\mathrm{x}_{1}$ & 84 & 1585400,82 & 14165749,79 & 0,02 & 129828462,00 \\
\hline $\mathrm{X}_{12}$ & 84 & 996814569,18 & 9105586362,43 & 0,00 & 83456941948,00 \\
\hline
\end{tabular}

Source: compiled by author.

As we can see, as of the second quarter of 2018, there were 84 banks in the banking system of Ukraine, which became the object of analysis. The average value was calculated by arithmetic mean of all values of the array. 
The standard deviation indicates the level of deviation or scattering of the values of a characteristic from its mean level and is a sign of absolute variation. It is considered that the smaller the standard deviation, the more rare is the population. The obtained values indicate the heterogeneity of the analyzed population. The minimum and maximum values are extreme limits of the analyzed indicators and even at this stage of the analysis can indicate the presence or absence of banking risks in the system. Yes, this is especially noticeable for the first five variables $\left(\mathrm{x}_{1}-\mathrm{x}_{5}\right)$. The indicators obtained will be appropriate for further stages of analysis. As of March 1, 2018, the coordinates of the vector of reference values for calculating the taxonomic indicator of banking risk assessment were as follows:

$$
L_{e t}=\left(\begin{array}{l}
25713085,73 \\
1345,62 \\
19562,89 \\
76868,55 \\
76870,18 \\
5228371252,14 \\
110621493493,10 \\
425839,74 \\
1,30 \\
1,51 \\
14165749,81 \\
9105586362,43
\end{array}\right)
$$

The taxonomic assessment results of bank risk assessment for the three quarters of 2018 by banks are shown in Figure 2.

Table 3. Grading of taxonomic indicator of bank riskiness

\begin{tabular}{|l|l|c|c|c|}
\hline \multirow{2}{*}{ Limits } & \multirow{2}{*}{ Indicator's estimate } & \multicolumn{3}{c|}{ The number of banks } \\
\cline { 3 - 5 } & & As of 01.03.2018 & As of 01.06.2018 & As of 01.09.2018 \\
\hline From 0 to 0,24 & Critical level & 82 & 83 & 81 \\
\hline From 0,25 to 0,49 & Low level & 1 & 0 & 2 \\
\hline From 0,50 to 0,74 & Average level & 1 & 1 & 0 \\
\hline From 0,75 to 1,00 & High level & 0 & 0 & \\
\hline
\end{tabular}

Source: compiled by author.

Based on the analysis of Figure 2 and Table 3, it can be argued that the banking system of Ukraine as a whole has a critical level of banking risk management. Only the Ukrainian Bank for Reconstruction and Development had an average level of banking risk management, but as of September 1, 2018 its value had moved to the low group. The other two banks with the best value for one position on the system were PJSC "ALPARI BANK" (as of 01.03.2018) and PJSC "DIVI BANK" (as of 01.09.2018). In particular, insolvent or troubled banks (mainly PJSC CB "FINANCIAL INITIATIVE”) have negative values.

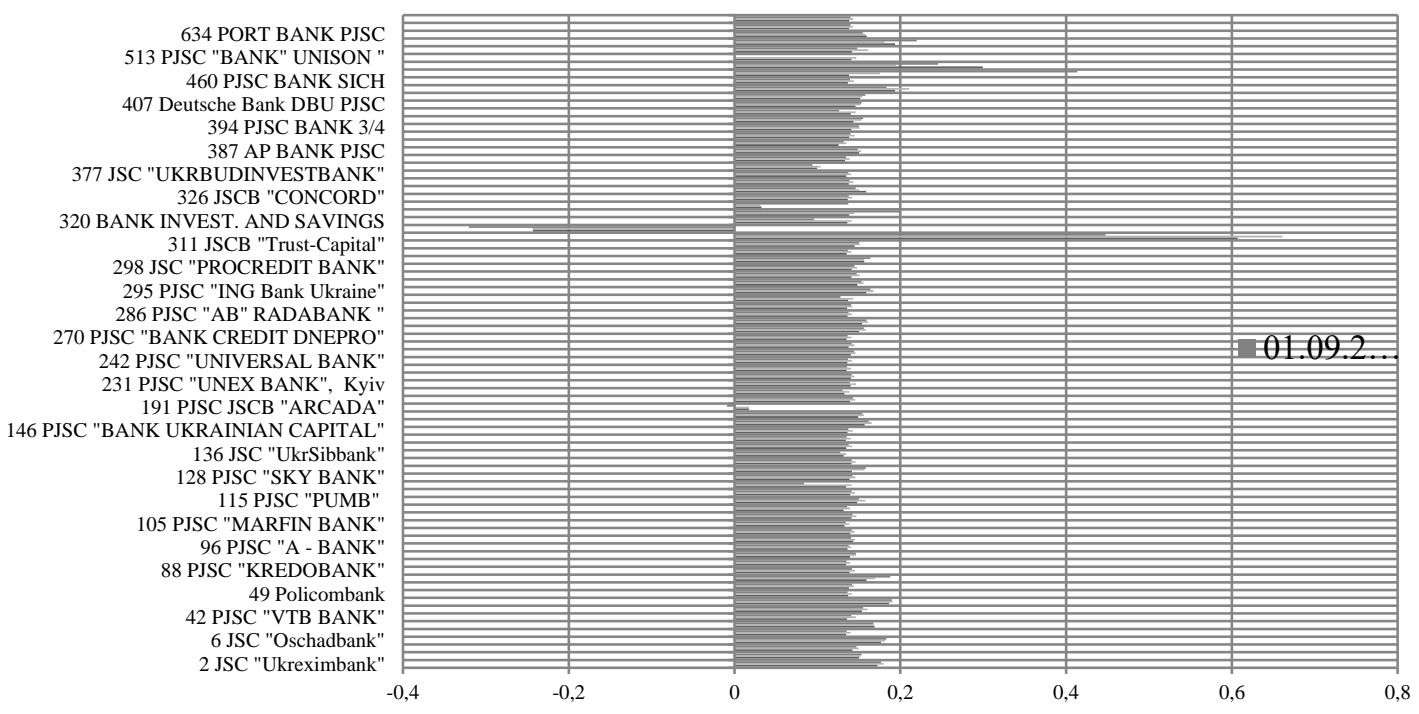

Figure 2. Comparison of the value of the integrated bank risk assessment indicator 
To interpretate the received data, we suggest to use the following scale of indicator's graduation (see Table 3).

\section{Part 2. The estimation of the taxonomic index of bank profitability}

The second major objective of the financial strategy for managing the financial position and performance of the bank is to maximize profits. To do this, we propose to consider the main indicators of bank profitability and to determine on their basis an integral indicator of estimating bank profit on the basis of similar steps of taxonomic analysis (see Figure 1).

We suggest to use the following indicators for the matrix of incoming observations (see Table 4).

Table 4. The characteristics of the main variables for estimating bank profit

\begin{tabular}{|c|c|c|}
\hline Variable & Characteristics & Direction of impact \\
\hline $\mathrm{x}_{1}$ & Overall level of profitability & Stimulator \\
\hline $\mathrm{x}_{2}$ & Payback of income & Stimulator \\
\hline $\mathrm{x}_{3}$ & Return on Assets (ROA) & Stimulator \\
\hline $\mathrm{x}_{4}$ & Return on Equity (ROE) & Stimulator \\
\hline $\mathrm{x}_{5}$ & Net interest margin & Stimulator \\
\hline
\end{tabular}

Source: compiled by author.

That is, an increase in profitability will have a positive effect on the bank's operations, which explains their role as stimulators. Descriptive statistics on profit management indicators for 84 Ukrainian banks as of 01.03.2018 have the following form (Table 5).

Table 5. Descriptive statistics for estimating bank profit as of 01.03.2018

\begin{tabular}{|c|c|c|c|c|c|}
\hline Variable & $\begin{array}{c}\text { Number of } \\
\text { observations }\end{array}$ & Mean value & Standard deviation & $\begin{array}{c}\text { Minimum } \\
\text { value }\end{array}$ & Maximum value \\
\hline $\mathrm{X}_{1}$ & 84 & 0,177 & 0,941 & $-4,620$ & 4,955 \\
\hline $\mathrm{X}_{2}$ & 84 & 1,156 & 1,382 & $-4,923$ & 7,304 \\
\hline $\mathrm{x}_{3}$ & 84 & 0,002 & 0,011 & $-0,064$ & 0,024 \\
\hline $\mathrm{X}_{4}$ & 84 & 0,020 & 0,053 & $-0,192$ & 0,224 \\
\hline $\mathrm{X}_{5}$ & 84 & 0,011 & 0,007 & $-0,001$ & 0,046 \\
\hline
\end{tabular}

Source: compiled by author.

Considering that the input data are already coefficients, we observe the relative homogeneity of the population. However, the values of the coefficients fluctuate to different limits, which became the basis for the decision to carry out indicators standardization according to formulas 2-4 and formation of a normative values matrix. The next step is to determine the reference vector similar to the previous calculations based on the maximum value (as the indicators are stimuli) with the standard deviation adjustment. So, here are the coordinates of the vector of reference values as of 01.03.2018 to calculate the taxonomic indicator of bank profit estimation:

$$
L_{e t}=\left(\begin{array}{c}
5,90 \\
8,69 \\
0,03 \\
0,28 \\
0,05
\end{array}\right)
$$

Next, we calculate the quasi-distances as the difference between the standardized and reference values of indicators and proceed to the definition of a generalized taxonomic indicator according to formulas 10-13. The results obtained are summarized in Figure 3. We group obtained indicators according to the previously accepted graduation scale in Table 6 by the levels of bank profit estimation.

Table 6. Graduation of the taxonomic index of the bank's profit estimation

\begin{tabular}{|l|l|c|c|c|}
\hline \multirow{2}{*}{ Limits } & \multirow{2}{*}{ Indicator's estimate } & \multicolumn{3}{c|}{ The number of banks } \\
\cline { 3 - 5 } & & As of 01.03.2018 & As of 01.06.2018 & As of 01.09.2018 \\
\hline From 0 to 0,24 & Critical level & 0 & 1 & 2 \\
\hline From 0,25 to 0,49 & Low level & 30 & 65 & 78 \\
\hline From 0,50 to 0,74 & Average level & 54 & 18 & 3 \\
\hline From 0,75 до 1,00 & High level & 0 & 0 & 0 \\
\hline
\end{tabular}

Source: compiled by author. 


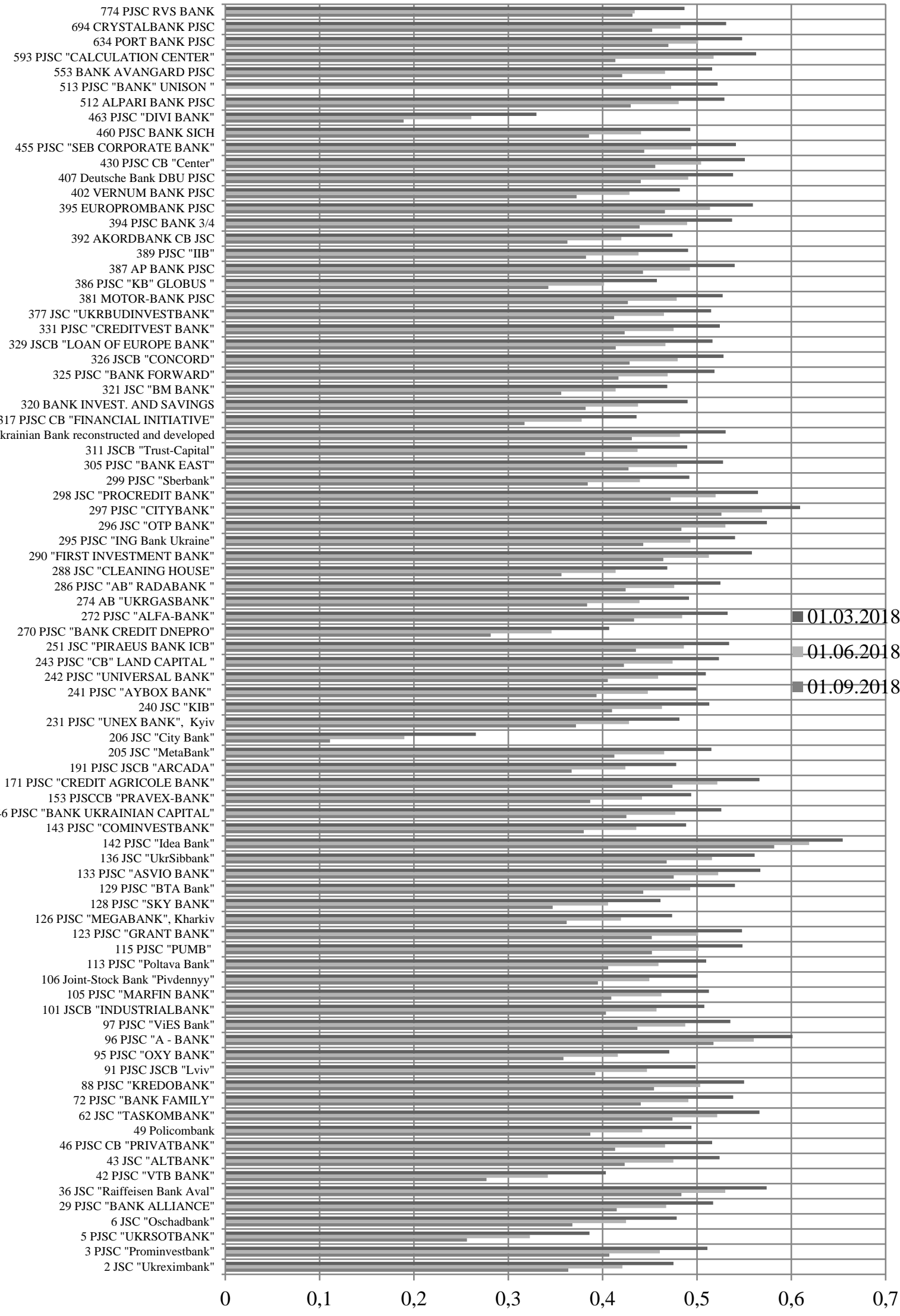

Figure 3. The comparison of integral indicator value of bank profit estimation

Source: compiled by author. 
As we can see, the bank's profit estimation mainly shows the distribution of banks among low and medium levels. Moreover, there is a significant shift of banks to lower levels of profit management, which is considered a negative trend. The critical level was observed in JSC "City Bank" and PJSC "DIVI BANK". Here, we observe a tendency for these banks to choose risk minimization as their orientation, but the return rate is rather low. Also, we consider it expedient to mention the banks that remained in the middle yield zone as of 01.09.2018 - PJSC "Idea Bank", PJSC "CITYBANK" and PJSC "A-BANK". It should be noted that these banks were in zone of critical level of risk. With regard to the insolvent bank of PJSC CB "FINANCIAL INITIATIVE", it is of average value, which is an additional evidence of the need for comprehensive analysis in the strategic management of the bank.

\section{Part 3: Research on the ratio of banking risk management and profit management}

These two goals of the bank's financial strategy namely minimizing banking risks and maximizing profitability are the main tasks of financial management. In the economic literature, even the so-called dilemma "income (risk) - risk", which determines the direction of the institution development strategy. Thus, by focusing on the first component (profit maximization), the bank will receive maximum profit, although the riskiness of the activity will be high enough. The second strategy is to minimize banking risks, but profits will grow at a slower pace. These calculations are a direct confirmation of this trend. For a more detailed analysis, we propose to build matrices that determine the ratio of risk-income categories based on the results of the taxonomic study (see Figures 4-6). Such data visualization will allow to understand the main focus of the financial strategy of the analyzed banks and to form conditional clusters on the basis of the proposed ratio.

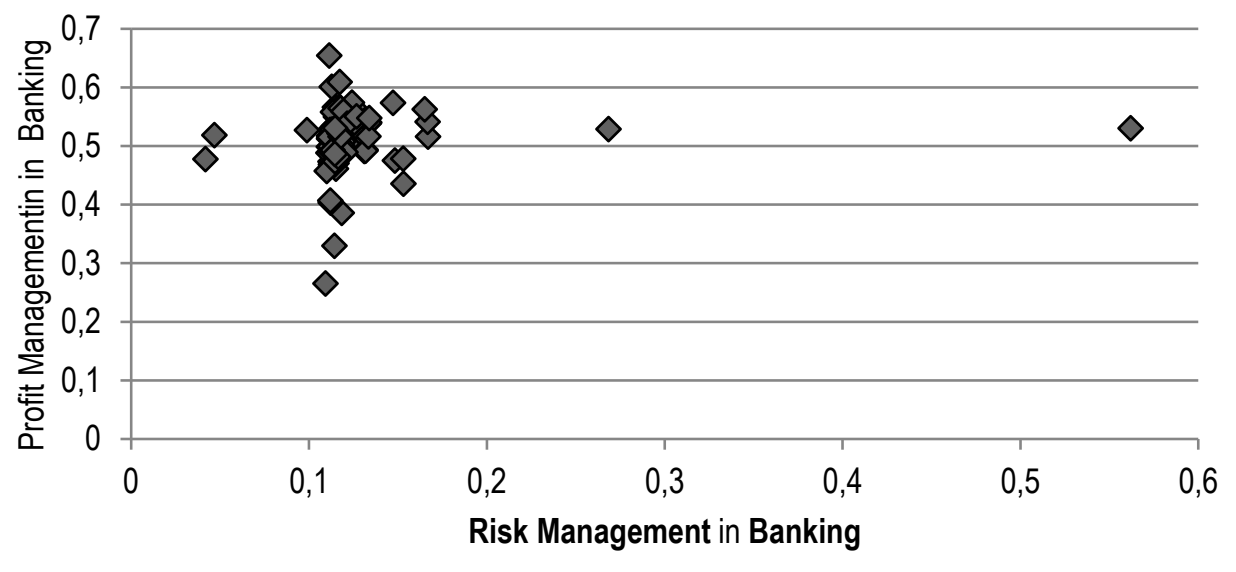

Figure 4. The distribution of Ukrainian commercial banks according to the ratio banking risk management and profit management as of 01.03.2018

Source: compiled by author.

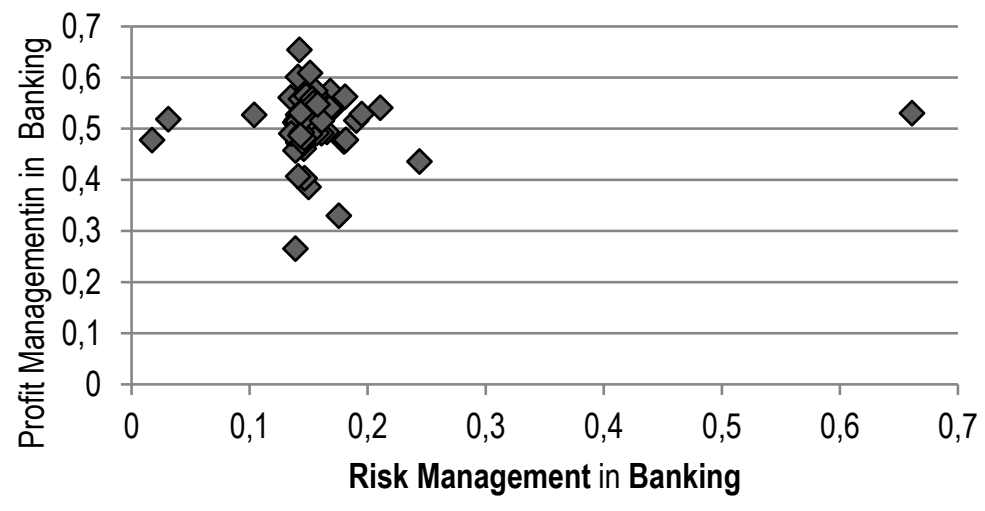

Figure 5. The distribution of Ukrainian commercial banks according to the ratio banking risk management and profit management as of 01.06.2018

Source: compiled by author. 


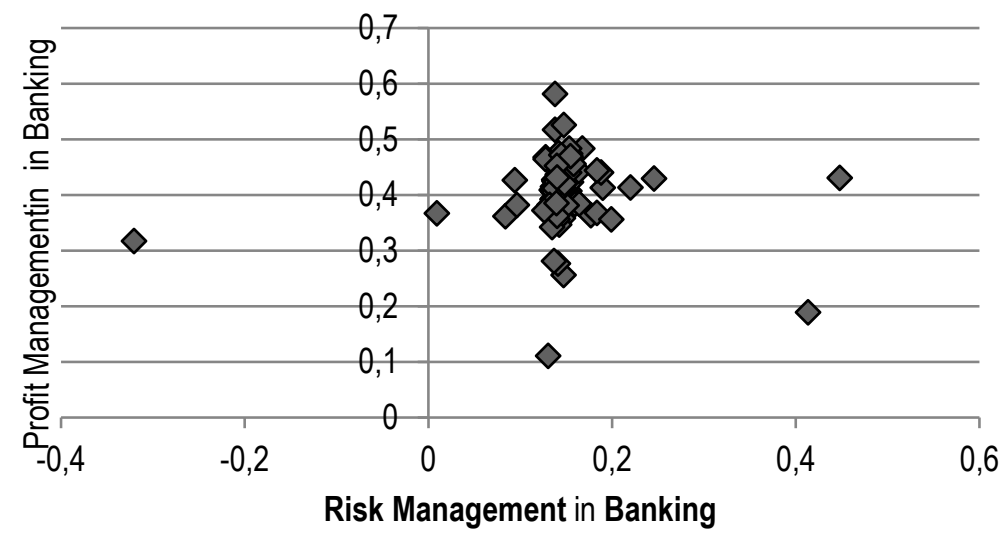

\section{Figure 6. The distribution of Ukrainian commercial banks according to the ratio banking risk management and profit management as of 01.09.2018}

Source: compiled by author.

Thus, we observe similar trends in the orientation of the commercial banks' financial strategy for different quarters of 2018. This is natural enough and shows that the long-term course of development of institutions is unchanged. Considering the above charts, we observe the prevailing focus of banks on maximizing profits, offsetting high riskiness of activity. The negative value in the last chart refers to the insolvent bank of PJSC CB "FINANCIAL INITIATIVE". In addition, we observe that some banks have a combination of goals through the application of a comprehensive financial strategy that allows them to achieve optimal results in both directions. In particular, this concerns the Ukrainian Bank for Reconstruction and Development.

\section{Conclusions, Discussion and Recommendations}

Summarizing the above study, it should be noted that risk and profitability assessment should be an important component of financial strategy in any commercial bank. The author proposed his own approach to their estimation, which is to calculate the integral indicators by taxonomic analysis based on data on the commercial banks activity in Ukraine for the first three quarters of 2018. Banking risk assessment was made on the basis of indicators of economic norms and open currency position limits for regulating banking activities and the main NBU instruments for ensuring the banking system stability. On the basis of the proposed graduation of the taxonomic indicator of banks' riskiness, it is possible to state in general the critical level of their management in Ukrainian banks. The bank's profitability was estimated based on the main indicators of bank profitability. The calculations show a medium and low level of profit management. Regarding the study of the relationship between banking risk management and profit management by means of the matrix method, the following trend should be noted. Most Ukrainian commercial banks are focused on maximizing profits by offsetting the high riskiness of their financial strategy. The combination of these two development vectors is quite rare in the Ukrainian banking market.

\section{References}

1. Bobyl, V. (2016). Finansovi ryzyky bankiv: teoriya ta praktyka upravlinnya v umovakh kryzy [Financial risks of banks: theory and practice of crisis management]: monograph. Dnipropetrovsk National University of Railway Transport V. V. Lazaryan. Dnepropetrovsk, 300 p. http://eadnurt.diit.edu.ua/bitstream/123456789/9572/1/Bobyl.pdf

2. Boykivska, L. I. (2009). Metody otsinok bankivs'kykh ryzykiv [Methods of bank risk assessment]. Actual Problems of Regional Development, 5, 164-168. http://base.dnsgb.com.ua/files/journal/Aktualniproblemy-rozvytku-ekonomiky-regionu/2009_5_2/40.pdf

3. Vasyleva, T. A., Dydenko, O. N., Epyfanov, A. A. and oth. (2005). Rysk-menedzhment ynnovatsyy [Innovation risk management]. Sumy: Business Perspectives, $260 \mathrm{p}$. https://essuir.sumdu.edu.ua/handle/123456789/50185?mode=full

4. Vnukova, N. M., Menshova, A. Yu. (2009). Upravlinnya ryzykamy kredytuvannya v banku [Bank lending risk management]. Financial and credit activity: problems of theory and practice, 1 (6). DOI: http: //dx.doi.org/10.18371/fcaptp.v1i6.29659. 
5. Vlasova, K. É., Kyrova, E. V (2010). Fynansovaya stratehyya: teoretycheskye osnovy y metodyka razrabotky [Financial strategy: theoretical foundations and methodology of development]. Modern Management: Problems and Solutions: Proceedings of the International Correspondence Scientific and Practical Conference (February 1, 2010). - Novosibirsk, 62-71. https://sibac. info/conf/manag/ia/51429

6. Goncharenko, O. M. (2015). Finansova stratehiya: teoretychni pytannya rozrobky ta realizatsiyi [Financial strategy: theoretical issues of development and implementation]. Bulletin of socio-economic research, Iss. 1, 56, 35-40. http://vsed.oneu.edu.ua/collections/2015/56/pdf/35-40.pdf

7. Kaylyuk, Y. E. M., Andryeyeva, V. M., Hrynenko, V. V. (2010). Stratehichnyy menedzhment [Strategic Management]: Educ. tool. Hark. nat. Acad. the city. master. $X$. KNAMG. 279 p. http://eprints.kname.edu.ua/17117/1/\%D0\%9D\%D0\%B0\%D0\%B2\%D1\%87_\%D0\%BF\%D0\%BE\%D1 \%81_\%D0\%BF_35\%D0\%9D_2010.pdf

8. Kozmenko, S.M., Spieg, F.I., Voloshko, I.V. (2010). Stratehichnyy menedzhment banku [Strategic management of the bank]. Sumy: University Book. 752 p. https://essuir.sumdu.edu.ua/handle/123456789/50329

9. Krasnova, I.V, Kotsyuba, I.I. (2014). Sutnist' ta klasyfikatsiya bankivs'kykh finansovykh stratehiy. [The essence and classification of banking financial strategies]. Kherson State University Scientific Bulletin, Issue 9-1, Part 4, 154-158. http://www.ej.kherson.ua/journal/economic 09-1/195.pdf

10. Krykliy, O.A., Maslak, N.H.. (2008). Upravlinnya prybutkom banku [Bank Profit Management]. Sumy: DVBS "UABS NBU", 136 p. https://essuir.sumdu.edu.ua/bitstream/123456789/52175/5/Kryklii_Upravlinnia_kredytnym_ryzykom_b anku.pdf

11. Kirizleyeva, A. S. (2016). Asset and liability management model in banks. Bulletin of the South Ural State University. Series: Economics and Management, vol. 10, no. 4, 2016, pp. 47-53. https://cyberleninka.ru/article/n/model-upravleniya-aktivami-i-passivami-v-bankah.

12. Lysenok, O. V. (2011). Upravlinnya dokhodamy ta vytratamy - osnova zabezpechennya finansovoyi stiykosti bankiv [Revenue and expenditure management is the basis for ensuring the financial soundness of banks]. Effective Economy, 12. http://nbuv.gov.ua/UJRN/efek_2011_12_77.

13. Lisichkin, V.A., Lisichkina, M.V. (2007). Strategicheskiy menedzhment [Strategic management]: educational-methodical complex. Moscow: Publishing. EAOI Center, 329 p. http://elibrary.bsu.az/books 200/N 161.pdf.

14. Litvinova, V.A. (2012). Povyshenye korrektnosty sravnytel'nykh otsenok konkurentosposobnosty produktsyy na osnove taksonomycheskoho metoda [Increasing the correctness of comparative estimates of product competitiveness based on the taxonomic method]. Innovative Economics, 5 (31), 97-101. http://dspace.oneu.edu.ua/jspui/handle/123456789/2016

15. Perepelova, V. B. (2013). Zastosuvannya taksonomichnoho analizu dlya vyznachennya intehral'noho pokaznyka otsinky finansovoho stanu pidpryyemstva [The use of taxonomic analysis to determine the integral indicator of assessing the financial condition of the enterprise]. Development Management, 18, 120-124. http://nbuv.gov.ua/UJRN/Uproz_2013_18_42.

16. Salo, I., Verkhusha, N. (2014). Naukovo-metodychni pidkhody do identyfikatsiyi ta otsinky kredytnoho ryzyku banku [Scientific and methodological approaches to identification and assessment of bank credit risk]. Financial And Credit Activity: Problems Of Theory And Practice, 1 (10). DOI: http: //dx.doi.org/10.18371/fcaptp.v1i10.29136.

17. Sokyrynska, I. H., Zhuravlova, T.O. (2016). Finansovyy menedzhment $u$ banku [Bank financial management]. Dnepropetrovsk:
https://nmetau.edu.ua/file/navch pos fmb sokir zhuravl izdat.pdf.

18. Shvarts, O. (2011). Udoskonalennya instrumentariyu upravlinnya aktyvamy i pasyvamy banku v umovakh finansovoyi nestabil'nosti. [Improvement of the Bank's assets and liabilities management instruments in the conditions of financial instability]. World of Finance, 4, 33-39. http://nbuv.gov.ua/UJRN/svitfin_2011_4_6. 